\title{
Impaired endocytosis in proximal tubule from subchronic exposure to cadmium involves angiotensin II type 1 and cubilin receptors
}

Mitzi Paola Santoyo-Sánchez ${ }^{1}$, José Pedraza-Chaverri ${ }^{2}$ Eduardo Molina-Jijón ${ }^{3}$, Laura Arreola-Mendoza ${ }^{4}$, Rafael Rodríguez-Muñoz ${ }^{3}$ and Olivier Christophe Barbier ${ }^{1^{*}}$

\begin{abstract}
Background: Chronic exposure to low cadmium (Cd) levels produces urinary excretion of low molecular weight proteins, which is considered the critical effect of $\mathrm{Cd}$ exposure. However, the mechanisms involved in $\mathrm{Cd}$-induced proteinuria are not entirely clear. Therefore, the present study was designed to evaluate the possible role of megalin and cubilin (important endocytic receptors in proximal tubule cells) and angiotensin II type 1 (AT1) receptor on Cd-induced microalbuminuria.

Methods: Four groups of female Wistar rats were studied. Control (CT) group, vehicle-treated rats; LOS group, rats treated with losartan (an AT1 antagonist) from weeks 5 to 8 (10 mg/kg/day by gavage); Cd group, rats subchronically exposed to $\mathrm{Cd}(3 \mathrm{mg} / \mathrm{kg} /$ day by gavage) during 8 weeks, and $\mathrm{Cd}+\mathrm{LOS}$ group, rats treated with $\mathrm{Cd}$ for 8 weeks and LOS from weeks 5-8. Kidney Cd content, glomerular function (evaluated by creatinine clearance and plasma creatinine), kidney injury and tubular function (evaluated by Kim-1 expression, urinary excretion of $\mathrm{N}$-acetyl- $\beta$-D-glucosaminidase (NAG) and glucose, and microalbuminuria), oxidative stress (measured by lipid peroxidation and $\mathrm{NAD}(\mathrm{P}) \mathrm{H}$ oxidase activity), mRNA levels of megalin, expressions of megalin and cubilin (by confocal microscopy) and AT1 receptor (by Western blot), were measured in the different experimental groups. Data were analyzed by one-way ANOVA or Kruskal-Wallis test using GraphPad Prism 5 software (Version 5.00). $\mathrm{P}<0.05$ was considered statistically significant.

Results: Administration of Cd (Cd and Cd + LOS groups) increased renal Cd content. LOS-treatment decreased $\mathrm{Cd}$-induced microalbuminuria without changes in: plasma creatinine, creatinine clearance, urinary NAG and glucose, oxidative stress, mRNA levels of megalin and cubilin, neither protein expression of megalin nor AT1 receptor, in the different experimental groups studied. However, $\mathrm{Cd}$ exposure did induce the expression of the tubular injury marker Kim-1 and decreased cubilin protein levels in proximal tubule cells whereas LOS-treatment restored cubilin levels and suppressed Kim-1 expression.
\end{abstract}

Conclusion: LOS treatment decreased microalbuminuria induced by $\mathrm{Cd}$ apparently through a cubilin receptor-dependent mechanism but independent of megalin.

Keywords: Cadmium, Subchronic exposure, Endocytosis, Megalin, Cubilin, Angiotensin II type 1 receptor, Losartan

\footnotetext{
* Correspondence: obarbier@cinvestav.mx

'Departamento de Toxicología, Centro de Investigación y de Estudios Avanzados del Instituto Politécnico Nacional (CINVESTAV-IPN), Mexico City, México

Full list of author information is available at the end of the article
}

\section{Biomed Central}

(c) 2013 Santoyo-Sánchez et al.; licensee BioMed Central Ltd. This is an open access article distributed under the terms of the Creative Commons Attribution License (http://creativecommons.org/licenses/by/2.0), which permits unrestricted use, distribution, and reproduction in any medium, provided the original work is properly cited. 


\section{Background}

Cadmium (Cd) is a heavy metal found in the earth's crust associated with lead, zinc and copper. Currently, this metal has become an environmental and public health problem due to its constant release by industrial activity. However, $\mathrm{Cd}$ is used for the manufacture of batteries, pigments, consumer electronics, and quantum dots $[1,2]$. This metal enters the food chain through contaminated air, water, and soils where it is caught and fixed by plants (ie. sunflower kernels and rice), molluscs and crustaceans (Cd contents $>1-2 \mathrm{mg} / \mathrm{kg} \mathrm{ww}$ ) [3-5]. In consequence, general population is exposed to $\mathrm{Cd}$ by contaminated water and food $[4,6]$. Another important source of $\mathrm{Cd}$ is cigarette smoke at a concentrations of 1-2 $\mu \mathrm{g} \mathrm{Cd}$ per cigarette. Smokers have more $\mathrm{Cd}$ in blood and kidneys than non-smokers. Smoking a pack of cigarettes per day leads to an absorption of $1-3 \mu \mathrm{g}$ of $\mathrm{Cd}[1,4,7]$. The kidney is the main organ affected by chronic $\mathrm{Cd}$ exposure. Ninety percent of filtered $\mathrm{Cd}$ is reabsorbed in the proximal tubule particularly in the S1 and $\mathrm{S} 2$ segments $[8,9]$. It has been reported that $\mathrm{Cd}$ enters proximal tubular cells by different routes: endocytosis (Cd conjugated with metallothionein or low molecular thiols) and transporters such as zinc transporter 1(ZnT1), ATP-binding cassette protein $(\mathrm{ABC}$ protein; located at basolateral membrane), ZrT/Irt-like protein (ZIP), Divalent Metal Transporter 1 (DMT1), and $\mathrm{Na}^{+}$-amino acid co-transporters $[9,10]$. Inside the cell, $\mathrm{Cd}$ induces proteins such as metallothionein 1/2 (MT1/2) and interacts with their sulfhydryl groups, altering protein function $[11,12]$. Main nephrotoxic symptoms of Cd exposure are proteinuria, glycosuria, aminoaciduria, and phosphaturia similar to Fanconi's syndrome $[11,13]$. The Agency for Toxic Substances and Disease Registry (ATSDR) has determined a dose of $0.1 \mu \mathrm{g} \mathrm{Cd} / \mathrm{kg} /$ day as Minimal Risk level (MRL) based on low molecular weight proteinuria (LWP) during a chronic-oral exposure [1]. Different studies have been designed to elucidate the mechanisms by which $\mathrm{Cd}$ induces proteinuria [14-16]. However, it has been reported that $\mathrm{Cd}$ toxicity depends on dose, route of administration and time of exposure. The glomerulus retains large proteins $(>67 \mathrm{kDa})$, but low weight proteins pass freely through the glomerular barrier and are reabsorbed along the proximal tubule. Normally, a healthy adult excretes from 40 to $80 \mathrm{mg}$ of protein per day, from which 10 to $15 \mathrm{mg}$ is albumin $[17,18]$. Filtrated albumin is reabsorbed in the proximal tubule; therefore albuminuria may result from an over-filtration of plasma proteins, glomerular or tubular dysfunction $[17,19,20]$. Protein reabsorption at the proximal tubule is accomplished by receptor-mediated endocytosis. Two receptors responsible for endocytosis, megalin and cubilin, have been described as major players in this phenomena [21,22]. Megalin is a glycoprotein of $600 \mathrm{KDa}$, member of the low-density lipoprotein receptor
(LDLR) family. Megalin is a multiligand receptor with a large $\mathrm{NH}_{2}$-terminal extracellular domain rich in cysteine, a single transmembrane domain and a $\mathrm{COOH}$-terminal short cytoplasmic domain with NPXY motifs that are responsible for internalization mediated by clathrin [22-24]. On the other hand, cubilin is a peripheral membrane protein of $460 \mathrm{KDa}$, without transmembrane and cytoplasmic domains; cubilin contains $27 \mathrm{COOH}$-terminal CUB domains (complement subcomponents $\mathrm{C} 1 \mathrm{r} / \mathrm{C} 1 \mathrm{~s}$, Uegf) which are ligand binding. Cubilin has different ligands, including megalin. In the proximal tubule cells, cubilin is co-expressed with megalin, and interacts with it, forming a complex to be internalized [25]. A decrease in the expression of megalin receptor favors the presence of proteins into urine (as captesin B, RPB and albumin) [21] and cubilin deficiency leads to an increase in albumin excretion [26]. Endocytosis along the proximal tubule is regulated by different factors, including angiotensin II (Ang II), an active vasopeptide of the renin-angiotensin system (RAS). RAS is an hormonal system that begins with renin secretion; this enzyme acts upon its substrate angiotensinogen, resulting in the formation of angiotensin I (Ang I) which in turn is hydrolyzed and converted to Ang II by the angiotensin converting enzyme (ACE) $[27,28]$. It has been suggested that Ang II can downregulate megalin and the treatment with RAS inhibitors or AT1 receptor blockers decreases proteinuria and protects kidney function independent of the effect of drugs on blood pressure $[29,30]$. In diabetic rats the infusion of Ang II decreases megalin expression and albumin reabsorption, but AT1 receptor blockers may restore this effect [31]. Hosojima et al. (2009) proposed that Ang II negatively regulates megalin expression at both mRNA and proteins levels, through the AT1 receptor and ERK pathway activation [32]. On the other hand, there is evidence that the RAS is implicated in the toxicity of cadmium [33-35]. In the present study, we evaluated the role of the megalin-cubilin complex and AT1 receptor on tubular endocytosis of albumin during a subchronic exposure to $\mathrm{Cd}$ in rats.

\section{Methods}

\section{Animals and treatment}

Female Wistar rats (180-220 g bw) were used. Animals were housed with $12 / 12$-h light/dark cycles at $22 \pm 1^{\circ} \mathrm{C}$, $50 \pm 5 \%$ humidity and received standard chow (PMI, 5008, Purina, Alief City, TX) and purified water ad libitum. The use of animals was in accordance with the Institute for Laboratory Animal Research (ILAR) Guide for Care and Use of Laboratory Animals and was approved by the Institutional Ethical Committee at Cinvestav, CICUAL [Comité Interno para el Cuidado y Uso de los Animales de Laboratorio; Number 391-07].

Rats were divided into four groups: 1) Control (CT): rats were administered with water by gavage for eight 
weeks. 2) LOS: from the fifth week on, the rats were administered with Losartan, an AT1 antagonist (Cozaar, $50 \mathrm{mg}$, Merck Sharp and Dohme de México S.A. de C.V.) (10 mg/kg/day, by gavage). 3) Cd: rats were administered with cadmium chloride (CAS No. 10108-64-2, Sigma Aldrich) (3 mg/kg/day, by gavage) for 8 weeks (weeks 0-8). 4) Cd+LOS: rats were administered with $\mathrm{Cd}$ for 8 weeks and LOS from weeks 5 to 8 . One day after the end of treatment, rats were housed individually in metabolic cages to collect $16 \mathrm{~h}$ urine for the measurements of microalbuminuria, creatinine, $\mathrm{N}$-acetyl- $\beta$-D-glucosaminidase (NAG) and glucose. After urine collection, animals were sacrificed with an overdose of Nembutal (pentobarbital sodium, $50 \mathrm{mg} / 100 \mathrm{~g}$ bw, i.p.). The kidneys were removed and washed in cold PBS. A half of the right kidney was used to determine cadmium content and a second half was used to extract RNA for RT-PCR. A half of the left kidney was frozen at $-70^{\circ} \mathrm{C}$ using 2-methylbutane as cryoprotector for immunofluorescence assays and a second half was used to extract proteins for Western blot and oxidative stress measurements.

\section{Urine and plasma measurements}

Urine samples were centrifuged for $10 \mathrm{~min}$ at $1000 \times \mathrm{g}$, and aliquots were separated. Blood samples were obtained by cardiac puncture and centrifuged for $15 \mathrm{~min}$ at $2000 \times \mathrm{g}$ to obtain plasma. Creatinine was measured in plasma and urine using the Jaffé method (CR510, Randox Laboratories, San Diego, CA) and glucose was measured in urine by the hexokinase method (GL161, Randox Laboratories, San Diego, CA). Microalbuminuria was measured using the HemoCue Albumin 201 system. Urinary NAG was determined at $580 \mathrm{~nm}$ by using a colorimetric assay (Cat. No. 875 406; Roche diagnostic).

\section{Creatinine clearance was calculated using the standard equation$$
\mathrm{C}_{\mathrm{cr}}=\left(\mathrm{U}_{\mathrm{cr}} / \mathrm{P}_{\mathrm{cr}}\right) \mathrm{xJv}
$$

where $C_{c r}$ is the value of creatinine clearance $(\mu \mathrm{L} / \mathrm{min} /$ $100 \mathrm{~g} \mathrm{bw}), \mathrm{U}_{\mathrm{cr}}$ and $\mathrm{P}_{\mathrm{cr}}$ are the concentration values $(\mathrm{mg} / \mathrm{dL})$ of creatinine in urine and plasma, respectively, and $\mathrm{Jv}$ is the urinary flow rate $(\mu \mathrm{L} / \mathrm{min} / 100 \mathrm{~g} \mathrm{bw})$.

\section{Measurement of renal cadmium content}

The technique used to quantify Cd content was described previously by the Environmental Protection Agency (EPA) [36]. Kidney samples were weighed and digested in a solution (2:1) of nitric acid (9601-02, Reactive Grade, J.T. Baker, 69.9\% of purity) and hydrochloric acid (9535-02, Reactive Grade, J.T. Baker, 37.1\% of purity) plus $3 \mathrm{~mL}$ of hydrogen peroxide (2186, Reactive Grade, J.T. Baker, 30\% of purity) overnight. Afterwards, samples were heated to a temperature of $80-90^{\circ} \mathrm{C}$ until full organic matter digestion was observed by the release of nitrous fumes (yellow-orange). In order to remove any organic residue, $3 \mathrm{~mL}$ of hydrogen peroxide were added to samples for $5 \mathrm{~min}$, leaving the mixture to react at $80-90^{\circ} \mathrm{C}$ until the solution turned transparent. At the end of this period, the solution was filtered and diluted to $10 \mathrm{~mL}$ with deionized water. In the final solution, $\mathrm{Cd}$ concentration was quantified by a standard curve using atomic absorption direct aspiration flame (Perkin Elmer, AAnalyst 100), with detection limit of $0.008 \mathrm{mg} / \mathrm{L}$. The following calculation was performed to express the concentration in $\mathrm{mg} / \mathrm{g}$ tissue:

$$
\begin{gathered}
\mathrm{Cd}(\mathrm{mg} / \mathrm{g})=[\mathrm{Cd}(\mathrm{mg} / \mathrm{L})] * \text { Volume of dilution }(\mathrm{L}) \\
/ \text { weight of sample }(\mathrm{g})
\end{gathered}
$$

\section{Lipid peroxidation determination}

Renal cortex was homogenized in phosphate buffer (50 mM, pH 7.4) containing $10 \mu \mathrm{L}$ of butylated hydroxytoluene $(0.5 \mathrm{M})$ in acetonitrile. Subsequently, the homogenate was centrifuged for $10 \mathrm{~min}\left(3000 \mathrm{x} \mathrm{g}\right.$ at $\left.4^{\circ} \mathrm{C}\right)$. Protein concentrations of the supernatants were determined using the Lowry assay. The supernatants were mixed with a solution (1:3) of 1-methyl-2-phenylindole in a mixture of acetonitrile methanol (3:1), reactions were started adding $37 \% \mathrm{HCl}$. Later, samples were incubated for $40 \mathrm{~min}$ at $40^{\circ} \mathrm{C}$. Lipid peroxidation was evaluated by measuring 4-hydroxynonenal (4-HNE) and malondialdehyde (MDA) using a standard curve of tetramethoxypropane at $586 \mathrm{~nm}[37,38]$.

\section{$\mathrm{NAD}(\mathrm{P}) \mathrm{H}$ oxidase activity determination}

Renal cortex was homogenized in phosphate buffer (50 mM, pH 7.4; w/v 1:10), containing 1 mM EDTA, 0.1\% triton-X100 and protease inhibitors. Subsequently the homogenate was centrifuged for $10 \mathrm{~min}\left(6000 \mathrm{x} \mathrm{g}\right.$ at $\left.4^{\circ} \mathrm{C}\right)$. Supernatants were incubated with $0.02 \mathrm{mM}$ dihydroethidium (DHE), $0.05 \mathrm{mg} / \mathrm{ml}$ salmon testes DNA, and the corresponding substrate for $\mathrm{NAD}(\mathrm{P}) \mathrm{H}$ oxidase in a dark plate away from direct light and at $37^{\circ} \mathrm{C}$ for $30 \mathrm{~min}$. DHE is oxidized to ethidium (Eth) and is used as a marker of superoxide $\left(\mathrm{O}_{2}{ }^{-}\right)$formation. Eth-DNA fluorescence was measured at an excitation wavelength of $480 \mathrm{~nm}$ and an emission of $610 \mathrm{~nm}$ by using a fluorescence multimode microplate reader (Synergy HT; Biotek) [39]. 0.1 mM of $\mathrm{NADH}$ was used as a substrate in the reaction mixture. To further confirm that the activity of $\mathrm{NAD}(\mathrm{P}) \mathrm{H}$ oxidase contributes to the production of $\mathrm{O}_{2}{ }^{-}$; diphenylene iodonium (DPI, $0.1 \mathrm{mM}$ ) a NAD(P)H oxidase inhibitor, was used. The fluorescent signal of each sample was expressed as DHE fluorescence relative to the control. Protein concentrations of the supernatants were determined using the Lowry assay. 


\section{Immunofluorescence}

Kidneys were sectioned in a Leica CM1100 cryostat (sections of $8 \mu \mathrm{m}$ ) and the slices were transferred on gelatin-coated slides. The slices were fixed for $10 \mathrm{~min}$ with methanol at $-20^{\circ} \mathrm{C}$; thereafter the slices were washed with PBS (with $1 \mathrm{mM}$ calcium) and then permeabilized with $0.2 \%$ Triton-X100 for $5 \mathrm{~min}$ at room temperature, and afterwards, washed twice with PBS. After the blocking them for $1 \mathrm{~h}$ at room temperature with $1 \%(\mathrm{w} / \mathrm{v})$ IgG-free-albumin, the slices were incubated overnight at $4{ }^{\circ} \mathrm{C}$ with primary polyclonal goat anti-megalin antibody (sc-16478, Santa Cruz Biotechnology, Inc., dilution 1:50), polyclonal goat anti-cubilin antibody (sc-20609, Santa Cruz Biotechnology, Inc., dilution 1:50), polyclonal goat anti Kim-1 antibody (Cat. No. AF3689, R\&D System, dilution 1:500) or monoclonal mouse anti-dipeptidyl-peptidase (IV) antibody (MCA924, Serotec Ltd., Kidlington, Oxford, OK, dilution 1:500). After three washes for $5 \mathrm{~min}$ with PBS at room temperature, the secondary antibody Alexa-Fluor 594 donkey anti goat (A11058, Invitrogen, dilution 1:300), Alexa-Fluor 488 donkey anti goat (A11055, Invitrogen, dilution 1:500) or Alexa-Fluor 594 donkey anti mouse (A21203, Invitrogen, dilution 1:500) was added for $2 \mathrm{~h}$ at room temperature. Later, the slices were washed three times with PBS, and mounted with Vectashield H-1400 (Vector laboratories Inc. Burlingame, CA). The immunofluorescence was examined using a multiphotonic confocal microscope (Leica TCSSP5 MO PANDEM) and analyzed with Leica Microsystem LAS AF Lite software. Megalin and cubilin fluorescence intensity was quantified in three images from three different rats per group.

\section{Western-blot}

The renal cortex was homogenized in cold buffer $\mathrm{A}$ (250 $\mathrm{mM}$ sucrose, $5 \mathrm{mM}$ EDTA, $10 \mathrm{mM}$ HEPES, protease inhibitors at $\mathrm{pH} 7.8$ ), and then centrifuged at $4^{\circ} \mathrm{C}$ for $15 \mathrm{~min} 13000 \mathrm{x} \mathrm{g}$, the pellet was resuspended on ice cold buffer $\mathrm{B}\left(2 \mathrm{mM} \mathrm{CaCl}_{2}, 1 \mathrm{mM} \mathrm{MgCl}_{2}, 10 \mathrm{mM}\right.$ HEPES, $140 \mathrm{mM} \mathrm{NaCl}$, protease inhibitors, and 1\% Triton $\mathrm{X}-100$ at $\mathrm{pH}$ 7.8). Afterwards, the samples were centrifuged at $4^{\circ} \mathrm{C}$ for $30 \mathrm{~min}$ at $13000 \mathrm{x}$ g. Protein concentrations of the supernatants were determined using Pierce BCA protein assay (No. 23225, Thermo Scientific). The supernatants were electrophoresed on $12 \%$ SDS-PAGE polyacrylamide and the proteins were transferred to nitrocellulose membranes (Bio-Rad Laboratories). Membranes were blocked for $1 \mathrm{~h}$ with $5 \%$ low-fat dry milk, next the blots were incubated with primary rabbit anti-AT1 antibody (sc-579, Santa Cruz Biotechnology, Inc.), diluted 1:200 in $10 \mathrm{mM}$ PBS (Cat. No. 21300-058, Gibco by Life Technologies) containing 0.1\% tween overnight at $4^{\circ} \mathrm{C}$. Blots were washed three times for $10 \mathrm{~min}$ in $10 \mathrm{mM}$ PBS containing $0.1 \%$ tween and incubated for $1 \mathrm{~h}$ with the secondary antibody (goat antirabbit IgG 1:10000, sc-2004 Santa Cruz Biotechnology, Inc.) at room temperature. After three washes for $10 \mathrm{~min}$ in $10 \mathrm{mM}$ PBS containing $0.1 \%$ tween, the proteins were detected by a chemiluminescence assay (RPN 2109, Amersham).

\section{Real-time PCR}

The RNA was extracted withTrizol protocol, using $100 \mathrm{mg}$ of renal cortex; and the cDNA was synthetized with the ImProm-II Reverse Transcription system (A3800, Promega Corporation). The megalin and cubilin genes were analyzed by quantitative RT-PCR using the TaqMan system in a 7500 real time PCR system (Applied Biosystems). Fluorescence for each cycle was analyzed quantitatively, and gene expression was normalized for the expression of the housekeeping gene GAPDH (Part Number 4352338E, Applied Biosystems). The forward and reverse primers for megalin are listed in Table 1, and for the cubilin gene, a commercial TaqMan gene expression assay was used (Part Number 4331182, Applied Biosystems).

\section{Statistical analyses}

Data were analyzed by one-way ANOVA or KruskalWallis test using GraphPad Prims 5 software (Version 5.00). KS normality test and Bonferroni's or Dunn's poshoc test were used. $\mathrm{P}<0.05$ was considered statistically significant. The data are expressed as means \pm SEM.

\section{Results}

\section{Effect of $\mathrm{Cd}$ on body weight, water intake and renal} content

The first aim of this study was to explore the effect of $\mathrm{Cd}$ treatment on physiological parameters such as body weight, water intake and renal accumulation of this metal on the different treated groups at the end of the exposure period. Table 2 shows, no alterations on body weight in the different experimental groups. Interestingly, Cd + LOS group showed a significant increase in water intake (approximately 2-fold) when compared with CT, LOS and Cd groups.

As expected, gavage administration of $\mathrm{Cd}$ increased renal $\mathrm{Cd}$ content, which was significant in both, $\mathrm{Cd}$ and $\mathrm{Cd}+\mathrm{LOS}$ groups $(7.6 \mu \mathrm{g} / \mathrm{g}$ kidney) compared to $\mathrm{CT}$ and LOS groups $(0.087 \mu \mathrm{g} / \mathrm{g}$ kidney) (Table 2$)$.

\section{Table 1 List of primers used for megalin gene}

\begin{tabular}{ll}
\hline Rat megalin gen & Accession no. L34049 \\
\hline Forward primer & AATGCGGCAGTGGGAATIT \\
Reverse primer & ACACCCAGGAGCTAGGGAT \\
Probe & /5'6FAM/TGGCTGTCCTCCCA \\
& GGTCCTGC/3'TAMRA \\
\hline
\end{tabular}


Table 2 Effect of subchronic exposure to cadmium on body weight, water intake and renal cadmium content

\begin{tabular}{lcccc}
\hline $\begin{array}{l}\text { Experimental } \\
\text { group }\end{array}$ & CT & LOS & Cd & Cd + LOS \\
\hline Body weight $(\mathrm{g})$ & $263 \pm 19$ & $256 \pm 22$ & $263 \pm 21$ & $256 \pm 17$ \\
$\begin{array}{l}\text { Water intake } \\
(\mathrm{m} / 100 \mathrm{~g} / 16 \mathrm{~h})\end{array}$ & $8.33 \pm 2.94$ & $11.38 \pm 6.33$ & $10.20 \pm 3.84$ & $20.20 \pm 13.75^{\mathrm{a}, \mathrm{b}, \mathrm{c}}$ \\
$\begin{array}{l}\text { Renal Cd levels } \\
(\mu \mathrm{g} / \mathrm{g} \text { wet tissue) }\end{array}$ & $0.08 \pm 0.00$ & $0.08 \pm 0.00$ & $7.6 \pm 1.12^{\mathrm{d}, \mathrm{e}}$ & $7.6 \pm 0.97^{\mathrm{d}, \mathrm{e}}$ \\
\hline
\end{tabular}

LOS, losartan. Data represent the means $\pm \mathrm{SEM}, \mathrm{n}=9-10$. ${ }^{\mathrm{a}} \mathrm{P}<0.05$ vs $\mathrm{CT},{ }^{\mathrm{b}} \mathrm{P}<$ 0.05 vs $L O S,{ }^{C} \mathrm{P}<0.05$ vs $C d,{ }^{d} \mathrm{P}<0.001$ vs $C T,{ }^{e} \mathrm{P}<0.001$ vs $L O S$

\section{Effect of Cd on urinary flow rate, plasma creatinine and} creatinine clearance

To determine whether $\mathrm{Cd}$ alters renal function in our experimental conditions, we measured urinary flow rate (Jv) and estimated glomerular filtration rate (eGFR) determined by creatinine clearance (Figure 1 ).

Rats treated with $\mathrm{Cd}+\mathrm{LOS}$ showed increased urinary flow rate compared with CT $(\mathrm{p}<0.05)$, LOS $(\mathrm{p}<0.05)$, and $\mathrm{Cd}(\mathrm{p}<0.05)$ groups (Figure $1 \mathrm{~A})$. Meanwhile, no changes were found in plasma creatinine and creatinine clearance in the different treated groups (Figure1B and C) our results indicate that none of the treatments affected glomerular function.

\section{Effect of $\mathrm{Cd}$ on urinary glucose concentration, urinary NAG, microalbuminuria and Kim-1 expression}

In order to explore proximal tubular function, urinary concentrations of glucose, and NAG, and microalbuminuria were determined (Figure 2).

No changes were found in urinary excretion of glucose and NAG in the different treated groups. However, microalbuminuria was significantly increased in $\mathrm{Cd}$ treated animals when compared with control groups (CT and LOS treated rats) $(\mathrm{p}<0.05)$. Kim-1 was evaluated as an early biomarker of proximal tubule injury showing a clear expression only in rat kidneys of the $\mathrm{Cd}$ group (Figure 3 ). The co-administration with LOS reduced Kim-1 expression and decreased the microalbuminuria when it was compared to $\mathrm{Cd}$ treated rats (Cd vs. Cd + LOS; $\mathrm{p}<0.05)$, indicating a possible relationship between the impaired endocytosis and injury induced by $\mathrm{Cd}$ and the blockade of AT1 receptor with LOS.

\section{Effect of Cd on kidney oxidative stress}

Increased oxidative stress has been demonstrated to be involved in $\mathrm{Cd}$ toxicity and a possible relationship with proteinuria has been reported. To evaluate the redox status in the exposed animals, we measured malondialdehyde and 4-hydroxynonenal content in renal cortex (both used as markers of lipid peroxidation) (Table 3). No changes were found in lipid peroxidation in the four different treated groups. In order to explore the production of a specific reactive oxygen specie (ROS), we measured superoxide $\left(\mathrm{O}_{2}{ }^{-}\right)$production by assessing $\mathrm{NAD}(\mathrm{P}) \mathrm{H}$ oxidase activity, since it has been reported that the overactivation of this enzyme constitutes a major source of oxidative stress in the kidney [40]. Also, it has been documented that $\mathrm{NAD}(\mathrm{P}) \mathrm{H}$ oxidase is activated via Ang II through the AT1 receptor [41]. On Table 3, it can be observed that the rats treated with $\mathrm{Cd}+\mathrm{LOS}$ showed a significantly decrease activity of $\mathrm{NAD}(\mathrm{P}) \mathrm{H}$ oxidase compared to the CT group $(\mathrm{P}<0.05)$. Based on the abovedescribed results, it was concluded that under our experimental conditions Cd-treatment at 8 weeks did not induce oxidative stress imbalance.

\section{Effect of $\mathrm{Cd}$ on megalin expression}

Studies have demonstrated that megalin and cubilin receptors internalize albumin and LWP in tubular proximal cells [25]. To further determine whether megalin and cubilin could be involved in the decreased endocytosis (suggested by microalbuminuria observed in $\mathrm{Cd}$ treated rats); it was investigated whether Cd-treatment affected the localization and expression of megalin and cubilin by using confocal microscopy (Figure 4A and Figure 5A). The quantification of the fluorescence intensity was also evaluated (Figure $4 \mathrm{~B}$ and Figure 5B). As shown in Figure 4A, megalin label was observed in the apical membrane of epithelial proximal cells in the four different groups and no changes were found along the experimental groups. Consistently the quantification of fluorescence intensity showed no changes in the different groups (Figure 4B). Furthermore, Cd, LOS or $\mathrm{Cd}+\mathrm{LOS}$ treatments did not affect mRNA levels of megalin (Figure 4C). On the other hand, cubilin label, localized in the apical membrane of epithelial proximal cells was decreased in the $\mathrm{Cd}$ exposed group (Figure 5A) as confirmed by the quantification of fluorescence intensity showing statistically significant differences in the $\mathrm{Cd}$ group compared with the others groups (Figure $5 \mathrm{~B}$ ). Interestingly mRNA levels of cubilin were not modified by $\mathrm{Cd}$ exposure (Figure 5C). These findings suggest that cubilin might be participating in the increased microalbuminuria observed in the Cd-group whereas megalin might not.

\section{Effect of Cd on AT1 receptor expression}

Since LOS (an AT1 receptor antagonist) treatment decreased the impaired endocytosis induced by $\mathrm{Cd}$, it was decided to analyse the expression levels of AT1 in the different treated groups. As it can be seen in Figure 6, no changes were found in protein levels of AT1 receptor in the four groups studied (Figure 6A and B).

\section{Discussion}

Kidney is the main target organ of $\mathrm{Cd}$ exposure. Chronic exposure to low levels of $\mathrm{Cd}$ produces urinary waste of LWP, suggesting an alteration of endocytosis in the 


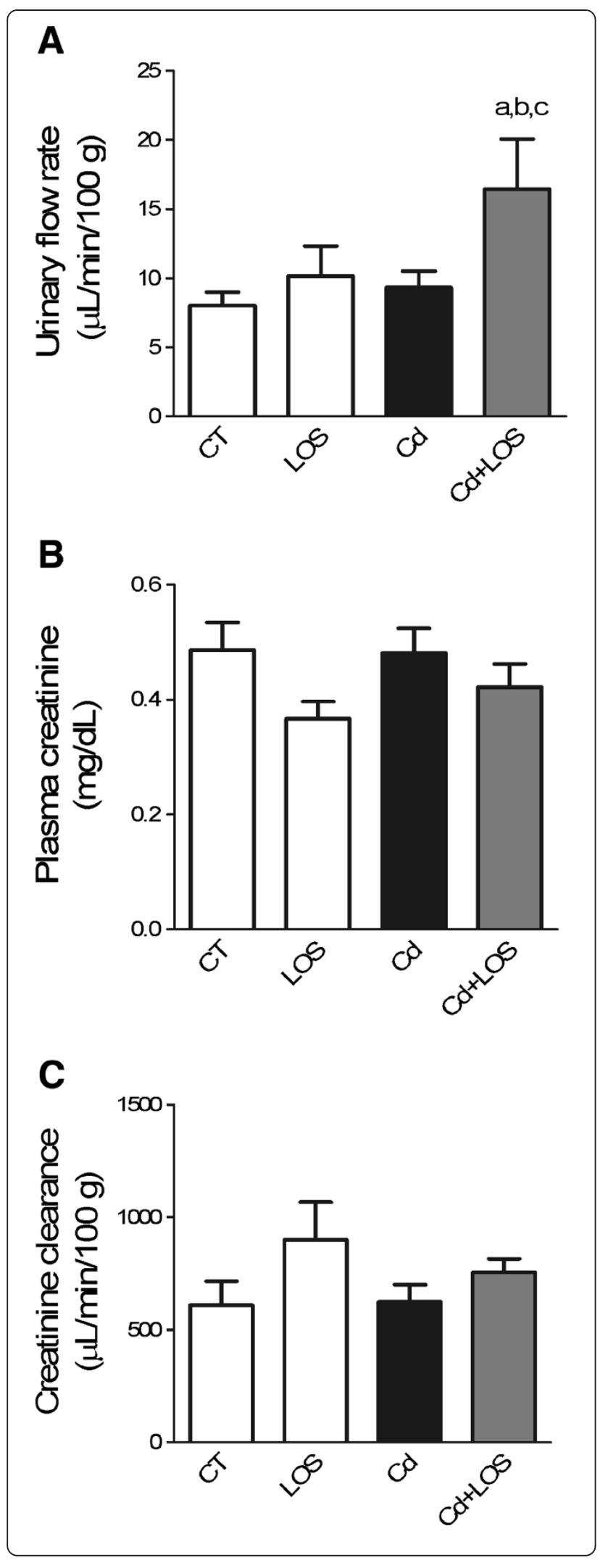

Figure 1 Effect of subchronic exposure to cadmium on renal function parameters. Urinary flow rate (A), increased in cadmium + losartan (Cd + LOS) group compared to control (CT), losartan (LOS), and cadmium (Cd) groups. Plasma creatinine (B), and creatinine clearance (C) did not change in the all experimental groups studied. Data are means $\pm S E M, n=9-10$ rats per group. ${ }^{a} P<0.05$ vs $C$, ${ }^{b} P<0.05$ vs $L O S$, ${ }^{c} \mathrm{P}<0.05$ vs $\mathrm{Cd}$. Urinary flow rate was analyzed with one way ANOVA and Bonferroni's multiple comparison test; plasma creatinine and creatinine clearance were analyzed with Kruskal-Wallis and Dunn's multiple comparison test.

proximal tubule. However, the mechanism responsible of $\mathrm{Cd}$-induced proteinuria is not fully understood. In normal physiological conditions, LWP can be filtered through the glomerulus, but they are reabsorbed by endocytosis in the proximal tubule. The megalin-cubilin complex is responsible for the endocytosis of proteins in the renal proximal tubule [25]. On the other hand, it has been observed that the use of RAS inhibitors prevents proteinuria in diabetic patients and rats [29-31,42]. Therefore, the aim of this study was to evaluate the role of megalin-cubilin complex and AT1 receptor on impaired tubular endocytosis of albumin during a subchronic exposure to $\mathrm{Cd}$. In this study, we decided to administrate $\mathrm{Cd}$ by gavage, for two main reasons: 1) to control the administered dose, and 2) oral route reflects the dietary exposure that is the most frequent route in the non-smoking population [4-6]. To better assess cellular mechanisms involved in Cd-nephrotoxicity, we decided to use a low dose that would not induce extensive damage in proximal tubules. Herein, the treatment with $3 \mathrm{mg} \mathrm{Cd} / \mathrm{kg} /$ day by gavage induced microalbuminuria. This effect was counteracted by treatment with LOS, which suggests the involvement of AngII and AT1 receptor in microalbuminuria induced by $\mathrm{Cd}$. Chronic exposure to $\mathrm{Cd}$ induced proteinuria; this effect has been observed in occupationally exposed populations $[7,43,44]$ and experimental studies have tried to elucidate the mechanism of $\mathrm{Cd}$ induced decrease in protein endocytosis. Choi et al. (1999) observed that in Opossum Kidney epithelial (OK) cells, endocytosis of albumin was inhibited by exposure to $\mathrm{Cd}$, but this effect was independent from substrate affinity or direct interaction of $\mathrm{Cd}$ on the endocytic receptor [16]. The albumin endocytosis occurs via a receptor-mediated mechanism. In the proximal tubule, there are two principal endocytic receptors: megalin and cubilin. Megalin is a large protein $\approx 600 \mathrm{kDa}$, and it is a receptor constitutively concentrated in proximal tubular brush-border, coated pits, and vesicles. This receptor has a cytoplasmic tail that contains an internalization motif (two NPXY and a NPXY-like); which mediates binding to adapter proteins and the formation of the endocytic vesicle (internalization mediated by clathrin) $[20,45]$. Cubilin is a peripheral membrane glycoprotein $(\approx 460 \mathrm{kDa})$, without transmembrane and intracellular domains, and is co-expressed with megalin in the proximal tubule. Cubilin also binds to proteins such as 


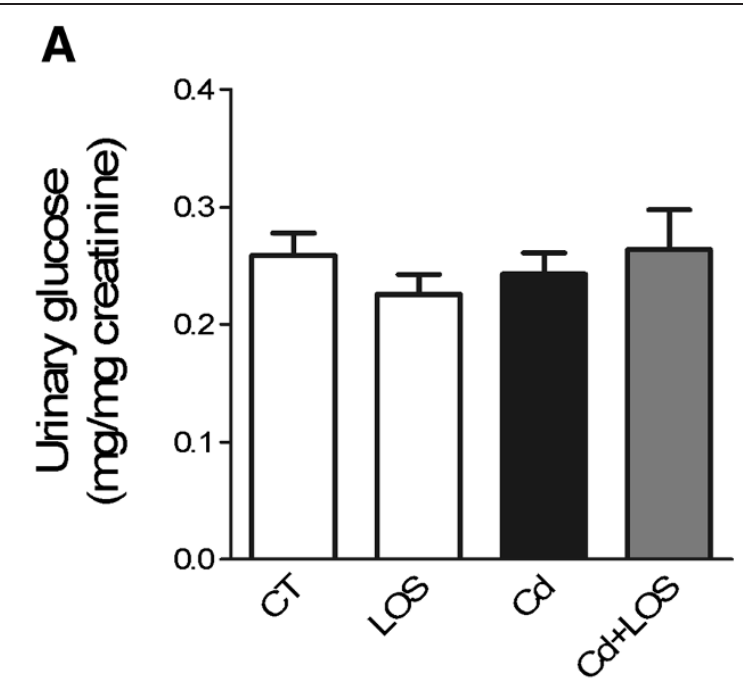

B

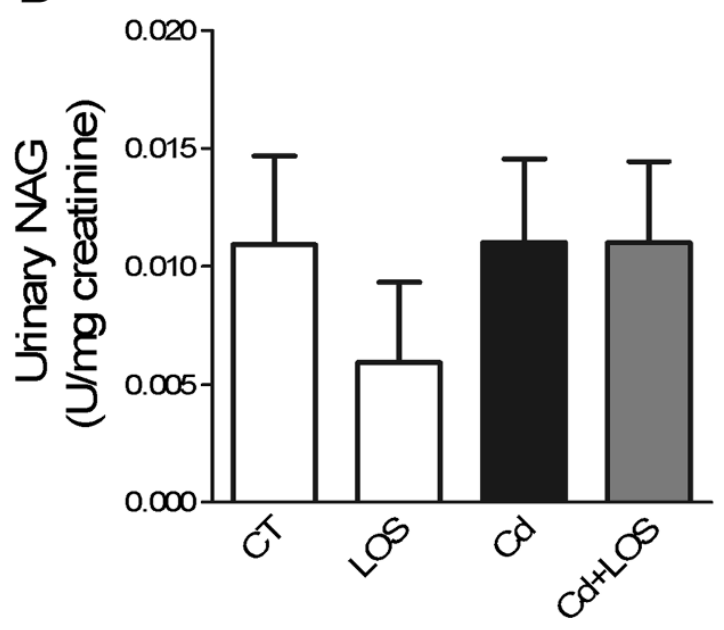

Figure 2 Effects of subchronic exposure to cadmium on markers of proximal tubule damage. Urinary glucose (A), $\mathrm{N}$-acetyl- $\beta$-D-glucosaminidase (NAG) (B), and microalbuminuria (C) in control (CT), losartan (LOS), cadmium (Cd) and cadmium + losartan (Cd + LOS) groups. Co-treatment with LOS (Cd + LOS group) decreased microalbuminuria induced by cadmium (Cd group). Urinary glucose (A) and NAG (B) did not change in the all experimental groups. Data are means \pm SEM. $n=9-10$ rats per group. ${ }^{\mathrm{a} P}<0.05$ vs $C T,{ }^{\mathrm{b}} \mathrm{P}<0.05$ vs $\operatorname{LOS},{ }^{\mathrm{d}} \mathrm{P}<0.05$ vs $\mathrm{Cd}+\mathrm{LOS}$. Urinary glucose and microalbuminuria were analyzed with one way ANOVA and Bonferroni's multiple comparison tests; urinary NAG was analyzed with Kruskal-Wallis and Dunn's multiple comparison tests.

albumin, and is considered essential for albumin reabsorption [26]. However, cubilin needs to bind megalin to be internalized. Although, cubilin also binds amnionless (AMN); a protein that colocalizes with it, and is important for the traffic of cubilin to the apical membrane [25]. Moreover, proteinuria induced by $\mathrm{Cd}$ exposure could be due to a) a decreased expression of membrane receptors involved in endocytosis, or b) inhibition of endocytosis via the alteration of one of the stages of this mechanism (internalization, vesicle recycling, or acidification of endo/lysosomes). Gena et al. (2010) observed that Cd exposure decreased megalin expression in Lilly Laboratory Cell Porcine Kidney cells (LLC-PK1) which was associated with impaired albumin endocytosis [14]. In our study, we analyzed the expression of both, protein and mRNA levels of megalin. In contrast with previous studies, no changes were observed in mRNA and protein levels of megalin in Cd-treated rats. Interestingly, expression of cubilin was decreased by $\mathrm{Cd}$ exposure without changes in mRNA levels; suggesting that $\mathrm{Cd}$ might induce a post-transcriptional modification of cubilin. After albumin filtration, this protein is reabsorbed along proximal tubule cells by endocytosis. Cubilin has

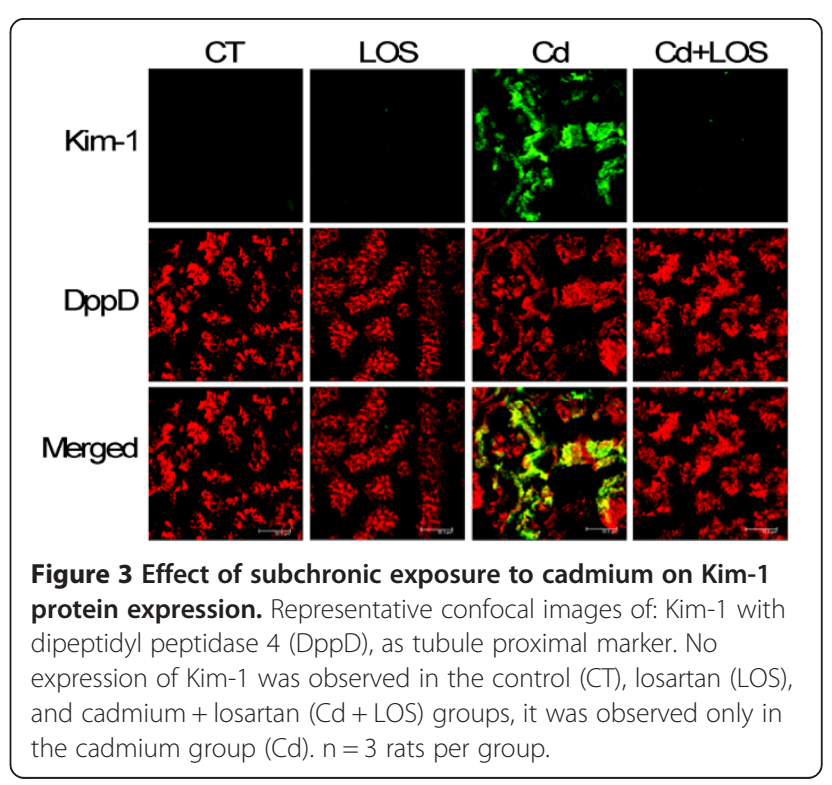


Table 3 Effect of subchronic exposure to cadmium on lipid peroxidation and NAD(P)H oxidase activity

\begin{tabular}{lllll}
\hline Experimental group & CT & LOS & Cd & Cd + LOS \\
\hline $\begin{array}{l}\text { Lipid peroxidation } \\
\text { (nmol MDA + }\end{array}$ & $2.58 \pm 0.42$ & $1.26 \pm 0.39$ & $1.52 \pm 0.26$ & $2.08 \pm 0.38$ \\
$\begin{array}{l}\text { 4-HNE/mg) } \\
\text { NAD(P)H oxidase }\end{array}$ & $8005 \pm 962$ & $5972 \pm 1560$ & $5415 \pm 1493$ & $3707 \pm 577^{\mathrm{a}}$ \\
activity (FU/mg) & & & & \\
\hline
\end{tabular}

LOS, losartan; MDA, malondialdehyde; 4-HNE, hydroxynonenal; $F U$, fluorescence unit. Data represent the means \pm SEM. $n=5$. ${ }^{a} P<0.05$ vs CT.

been considered the most important receptor in the albumin reabsorption $[26,46]$. In our study, microalbuminuria induced by $\mathrm{Cd}$ was attenuated with LOS, also cubilin levels were recovered in LOS-treated rats, indicating a possible relationship between cubilin receptor decrease and microalbuminuria. This data is in agreement with the findings reported by Oroszlán et al. (2010), where the treatment with ramipril (an ACE inhibitor) and LOS prevented downregulation of megalin and cubilin receptors induced by proliferation signal inhibitors (PSIs) [47]. Increased urinary albumin can be due to two factors: increased glomerular filtration rate and/or a decreased tubular reabsorption. In our model, glomerular function was evaluated by measuring plasma creatinine and creatinine clearance. No changes were found in both parameters evaluated in the four groups studied. Thus, glomerular function was not apparently affected after $\mathrm{Cd}$ exposure. In addition, urinary levels of glucose and NAG were unchanged by exposure to $\mathrm{Cd}$, suggesting the absence of severe proximal tubule damage. However, Kim-1 expression was increased after Cd exposure evidencing a tubular injury, which is consistent with the observations made by Prozialeck et al. (2007) where Kim-1 was proposed as an early biomarker of $\mathrm{Cd}$ nephrotoxicity [48]. In this study, LOS administration decreased Kim-1 expression and microalbuminuria induced by $\mathrm{Cd}$.

In addition to megalin and cubilin receptors; endocytosis involves multiple cellular components such as the endosome. The endosome needs some other molecular components for its optimal acidification: $\mathrm{Na}+/ \mathrm{H}+$ exchanger (NHE3), vacuolar proton-ATPase ( $\mathrm{v}-\mathrm{H}+-$ ATPase), and chloride channel 5 (ClC5) [45]. Absence of $\mathrm{ClC} 5$ is related to a dysfunctional endosomal acidification and therefore alterations in the reabsorption and the endocytosis, leading to a renal tubular disorder called Dent's disease. In an in vitro model, LLC-PK1 cells incubated with $10 \mu \mathrm{M}$ of $\mathrm{Cd}, \mathrm{ClC} 5$ expression was decreased after $3 \mathrm{~h}$ of exposure [14]. In in vivo models, some authors have observed that Cd exposure inhibits both $\mathrm{v}-\mathrm{H}^{+}$-ATPase [49] and NHE3 [50]. However, in these studies, rats received daily subcutaneous injections of $\mathrm{Cd}(2 \mathrm{mg} \mathrm{Cd} / \mathrm{kg} /$ day, 14 days or 3 weeks, respectively) reaching $\mathrm{Cd}$ concentrations in the kidney from 156 to $265 \mu \mathrm{g} / \mathrm{g}$ wet tissue. It is possible that
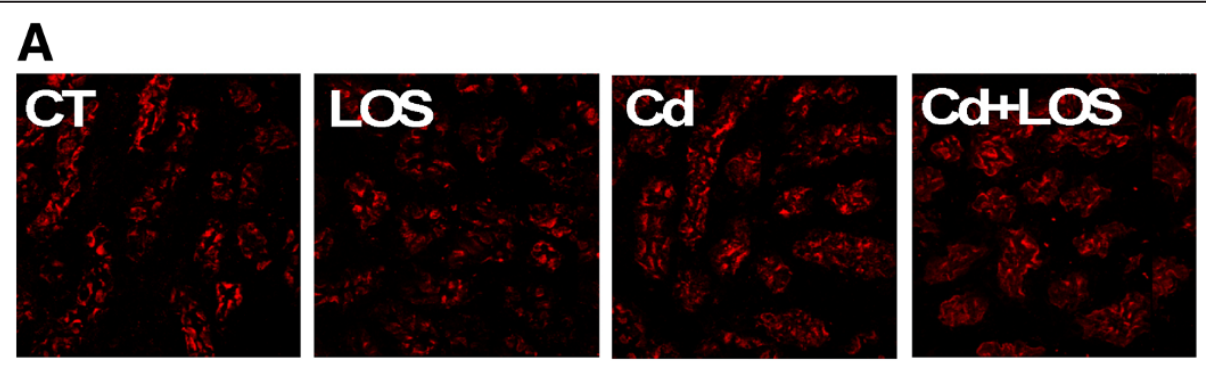

B

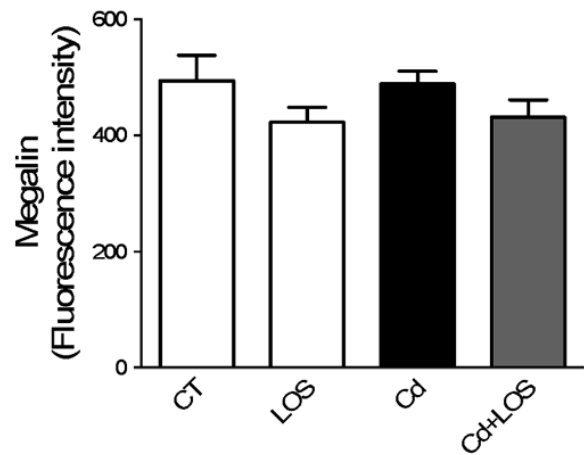

C

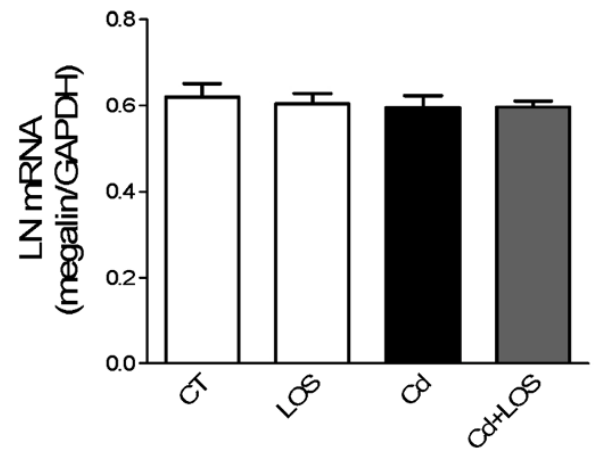

Figure 4 Effect of subchronic exposure to cadmium on megalin's mRNA and protein expression. Megalin expression did not change in losartan (LOS), cadmium (Cd) and cadmium + losartan (Cd + LOS) groups compared to control group (CT), as observed by immunofluorescence micrographs (A). Quantification of fluorescence intensity is shown in panel (B). mRNA levels of megalin did not change in the four experimental groups $(\mathbf{C})$. Data are expressed as LN mRNA of means \pm SEM, $n=3-10$ rats per group. Fluorescence intensity and mRNA were analyzed with one way ANOVA and Bonferroni's multiple comparison tests. 

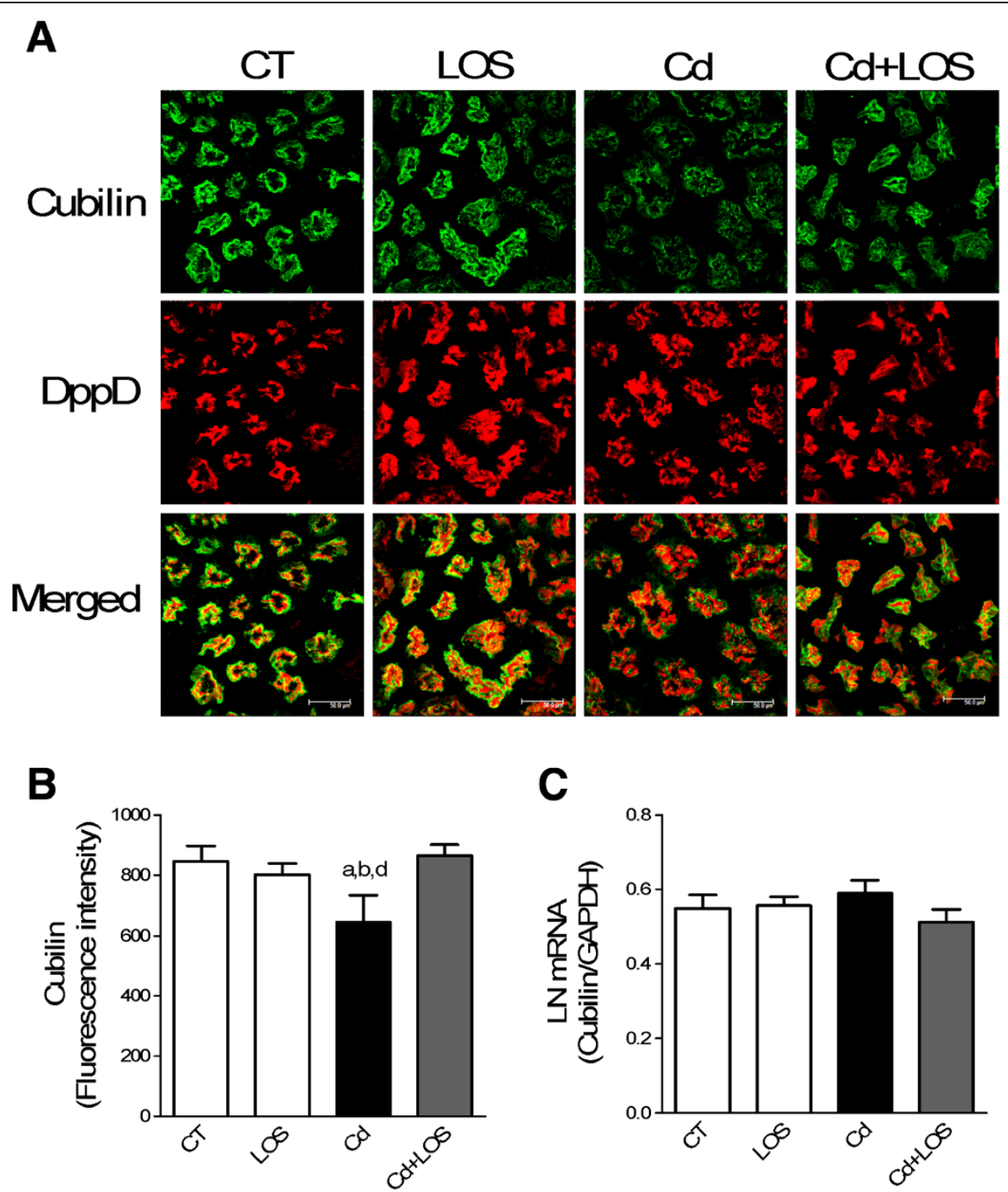

Figure 5 Effect of subchronic exposure to cadmium on cubilin's mRNA and protein expression. Cubilin expression did not change in losartan (LOS), and cadmium + losartan (Cd + LOS) groups compared to control group (CT), but was decreased in cadmium (Cd) group as observed by immunofluorescence micrographs (A). Quantification of fluorescence intensity is shown in panel (B). mRNA levels of cubilin did not change in the four experimental groups (C). Data are expressed as LN mRNA of means or fluorescence intensity \pm SEM, $n=3-10$ rats per group. Statistical analysis was performed with Kruskal-Wallis and Dunn's multiple comparison tests for fluorescence intensity, and one way ANOVA and Bonferroni's multiple comparison tests for mRNA levels.

in the above mentioned studies animals showed glomerular damage, due to, in both experiments, urinary flow and total protein excretion increased after Cd exposure.

To explore the mechanism of Cd toxicity, we evaluated oxidative stress by assessing lipid peroxidation. In our model, we did not observe changes on lipid peroxidation in any the groups studied. However, Wang et al. (2009) reported, that one of the mechanisms by which $\mathrm{Cd}$ induced nephrotoxicity is by reactive oxygen species (ROS) overproduction, inferred from the use of an antioxidant agent ( $\mathrm{N}$-acetyl cysteine) that protected against Cd-induced proteinuria [51]. Many other studies indicate that $\mathrm{Cd}$ promotes oxidative stress imbalance [52-54]. It is possible that we have not detected oxidative stress injury; may be due to the low amount of $\mathrm{Cd}$ and length of exposure $(3 \mathrm{mg} / \mathrm{kg} / \mathrm{day}$ for 8 weeks). Absorption of $\mathrm{Cd}$ on gastrointestinal tract is low $(\approx 5-10 \%)$, in our model, a low concentration of $\mathrm{Cd}$ reached the kidneys $(7.6 \mu \mathrm{g} / \mathrm{g}$ wet tissue), and it is possible that renal cells were still able to respond adequately to the oxidative insult. Thijssen et al. (2007) report that Cd exposure may trigger a biphasic defense response in the kidney, and could lead to adaptation and survival [55] maybe by induction of Nuclear factor erythroid 2 related factor 2 (Nrf2), this transcription factor binds to antioxidant response elements and regulates the expression of antioxidant genes [56]. On the 


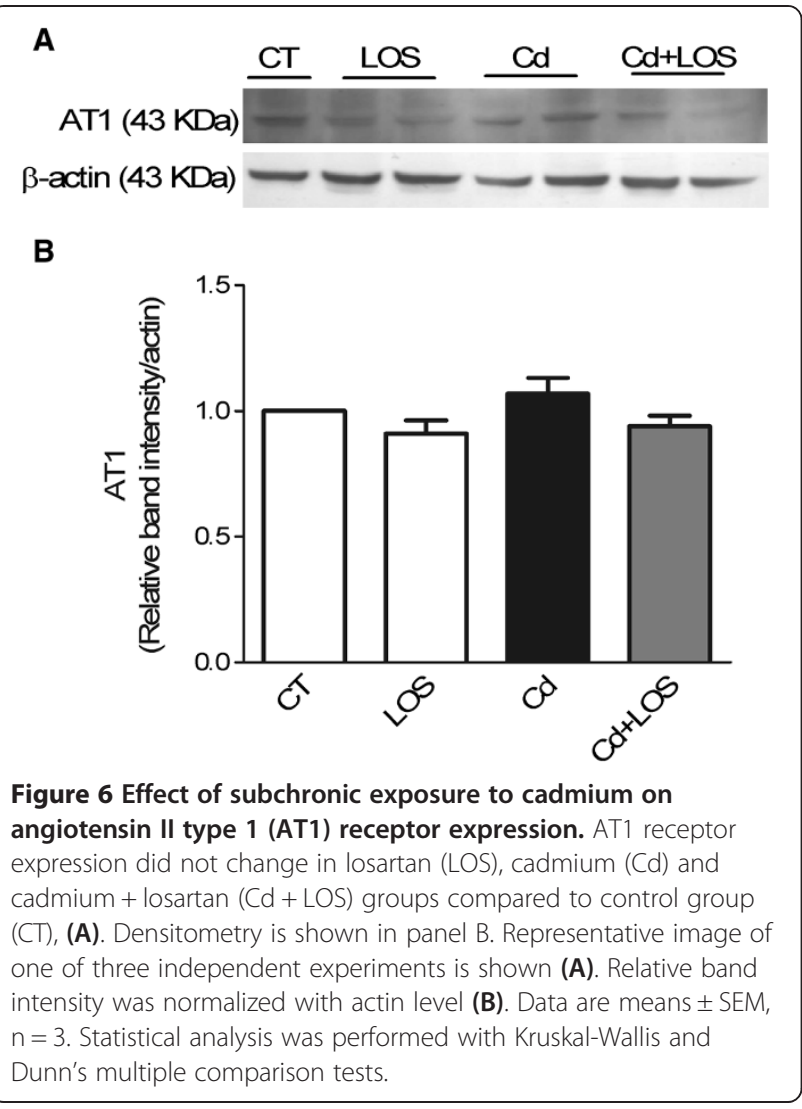

other hand, it has been suggested that $\mathrm{Cd}$ at low concentrations could modulate and inhibit $\mathrm{NAD}(\mathrm{P}) \mathrm{H}$ oxidase activity [57]. It has been reported that this enzyme is the one of the major sources of ROS in the kidney $[40,58]$. It is known that Ang II increases $\mathrm{NAD}(\mathrm{P}) \mathrm{H}$ oxidase activity through AT1 receptor [41]. We found a decreased NAD (P) $\mathrm{H}$ oxidase activity in the group treated with $\mathrm{Cd}+\mathrm{LOS}$. In our model, we did not find an increase in oxidative stress, probably due to an antioxidant response of cell.

The mechanism by which $\mathrm{Cd}$ decreases cubilin is still unclear. To explore this mechanism, we used LOS, an AT1 receptor antagonist, because endocytosis is regulated by many factors and amongst them Ang II appears to be one of them [32,59]. Moreover, other studies showed that Cd stimulates RAS [33-35] and the use of inhibitors has shown a protective effect on $\mathrm{Cd}$ toxicity $[60,61]$. Regarding endocytosis, Ang II acts on two receptors, AT1 and AT2, both are expressed in proximal tubular cells, and as well as components of RAS; and it has been observed that, in diabetic models, the use of RAS inhibitors (ACE inhibitors and Ang II type 1 receptor) restored the expression of megalin and in consequence albumin reabsorption [31,62]. In vitro models have shown that Ang II modulates albumin endocytosis via AT2-Protein Kinase B (PKB) activation [59]. Interestingly, Ang II through AT2 may regulate cubilin receptor and restore albumin endocytosis [47].

\section{Conclusion}

In conclusion, LOS treatment decreased the microalbuminuria induced by $\mathrm{Cd}$ by a mechanism independent of megalin, and probably dependent on cubilin, at least at this duration of exposure. Further experiments are required to determine the mechanism by which $\mathrm{Cd}$ regulates cubilin expression.

\section{Competing interests}

The authors declare that they have no competing interests.

\section{Authors' contributions}

MPSS and OCB, conception of the study; MPSS, EMJ, RRM, data collection; MPSS, RRM, EMJ, data analyses; MPSS wrote the first draft, which was refined by contributions of JPC, EMJ, LAM and OCB. All authors were involved in the interpretation of the data, read and approved the final manuscript.

\section{Acknowledgements}

This research was supported by the Consejo Nacional de Ciencia y Tecnología (CONACyT, grants 152416, 129838 and 204474), México. M.P. Santoyo-Sánchez had a fellowship from CONACyT (grant 28849). We are grateful to QBP Juana Narvaez Morales, MVZ Rafael Leyva Muñoz, and MVZ Maria Antonieta Lopez Lopez for their technical assistance and discussions and Dr. Andrea De Vizcaya for her helpful revision of the manuscript.

\section{Author details}

${ }^{1}$ Departamento de Toxicología, Centro de Investigación y de Estudios Avanzados del Instituto Politécnico Nacional (CINVESTAV-IPN), Mexico City, México. ${ }^{2}$ Departamento de Biología, Facultad de Química, Universidad Nacional Autónoma de México (UNAM), Mexico City, México. ${ }^{3}$ Departamento de Fisiología, Biofísica y Neurociencias, Centro de Investigación y de Estudios Avanzados del Instituto Politécnico Nacional (CINVESTAV-IPN), Mexico City, México. ${ }^{4}$ Departamento de Biociencias e Ingeniería, Centro Interdisciplinario de Investigaciones y Estudios sobre Medio Ambiente y Desarrollo del Instituto Politécnico Nacional (CIIEMAD-IPN), Mexico City, México.

Received: 20 June 2013 Accepted: 1 October 2013

Published: 5 October 2013

\section{References}

1. ATSDR: U.S. Toxicologycal profile for Cadmium. In Agency for Toxic Substance and Disease Registry. Atlanta: GA: Department of Health and Human Sevices, Public Health Service, Centers for Disease control; 2012.

2. Rzigalinski BA, Strobl JS: Cadmium-containing nanoparticles: perspectives on pharmacology and toxicology of quantum dots. Toxicol Appl Pharmacol 2009, 238(3):280-288.

3. Storelli MM, Marcotrigiano GO: Consumption of bivalve molluscs in Italy: estimated intake of cadmium and lead. Food Addit Contam 2001, 18(4):303-307.

4. Satarug S, Moore MR: Adverse health effects of chronic exposure to low-level cadmium in foodstuffs and cigarette smoke. Environ Health Perspect 2004, 112(10):1099-1103.

5. Reeves PG, Vanderpool RA: Cadmium burden of men and women who report regular consumption of confectionery sunflower kernels containing a natural abundance of cadmium. Environ Health Perspect 1997, 105(10):1098-1104.

6. Vahter M, Berglund M, Nermell B, Akesson A: Bioavailability of cadmium from shellfish and mixed diet in women. Toxicol Appl Pharmacol 1996, 136(2):332-341.

7. Jarup $L, A$ kesson A: Current status of cadmium as an environmental health problem. Toxicol Appl Pharmacol 2009, 238(3):201-208.

8. Dorian C, Gattone VH 2nd, Klaasen CD: Renal cadmium deposition and injury as a result of accumulation of cadmium-metallothionein (CdMT) by the proximal convoluted tubules-A light microscopic autoradiography study with 109CdMT. Toxicol Appl Pharmacol 1992, 114(2):173-181.

9. Barbier O, Jacquillet $G$, Tauc M, Cougnon M, Poujeol P: Effect of heavy metals on, and handling by, the kidney. Nephron Physiol 2005, 99(4):105-110. 
10. Soodvilai S, Nantavishit J, Muanprasat C, Chatsudthipong V: Renal organic cation transporters mediated cadmium-induced nephrotoxicity. Toxicol Lett 2011, 204(1):38-42.

11. Thevenod F: Nephrotoxicity and the proximal tubule. Insights from cadmium. Nephron Physiol 2003, 93(4):87-93.

12. Klaassen CD, Liu J, Choudhuri S: Metallothionein: an intracellular protein to protect against cadmium toxicity. Annu Rev Pharmacol Toxicol 1999, 39:267-294.

13. Jarup L, Berglund M, Elinder CG, Nordberg G, Vahter M: Health effects of cadmium exposure-a review of the literature and a risk estimate. Scand J Work Environ Health 1998, 24(Suppl 1):1-51.

14. Gena P, Calamita G, Guggino WB: Cadmium impairs albumin reabsorption by down-regulating megalin and $\mathrm{CIC} 5$ channels in renal proximal tubule cells. Environ Health Perspect 2010, 118(11):1551-1556.

15. Abouhamed M, Wolff NA, Lee WK, Smith CP, Thevenod F: Knockdown of endosomal/lysosomal divalent metal transporter 1 by RNA interference prevents cadmium-metallothionein-1 cytotoxicity in renal proximal tubule cells. Am J Physiol Renal Physiol 2007, 293(3):F705-F712.

16. Choi JS, Kim KR, Ahn DW, Park YS: Cadmium inhibits albumin endocytosis in opossum kidney epithelial cells. Toxicol Appl Pharmacol 1999, 161(2):146-152.

17. Gorriz JL, Martinez-Castelao A: Proteinuria: detection and role in native renal disease progression. Transplant Rev (Orlando) 2012, 26(1):3-13.

18. Hoyer JR, Seiler MW: Pathophysiology of Tamm-Horsfall protein. Kidney Int 1979, 16(3):279-289.

19. Thakker RV: The role of renal chloride channel mutations in kidney stone disease and nephrocalcinosis. Curr Opin Nephrol Hypertens 1998, 7(4):385-388.

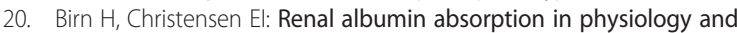
pathology. Kidney Int 2006, 69(3):440-449.

21. Leheste JR, Rolinski B, Vorum H, Hilpert J, Nykjaer A, Jacobsen C, Aucouturier $P$, Moskaug JO, Otto A, Christensen El, et al: Megalin knockout mice as an animal model of low molecular weight proteinuria. Am J Pathol 1999, 155(4):1361-1370.

22. Christensen El, Birn $\mathrm{H}$ : Megalin and cubilin: synergistic endocytic receptors in renal proximal tubule. Am J Physiol Renal Physiol 2001, 280(4):F562-F573.

23. Marzolo MP, Farfan P: New insights into the roles of megalin/LRP2 and the regulation of its functional expression. Biol Res 2011, 44(1):89-105.

24. Bansal A, Gierasch LM: The NPXY internalization signal of the LDL receptor adopts a reverse-turn conformation. Cell 1991, 67(6):1195-1201.

25. Christensen El, Birn H, Storm T, Weyer K, Nielsen R: Endocytic receptors in the renal proximal tubule. Physiology (Bethesda) 2012, 27(4):223-236.

26. Amsellem S, Gburek J, Hamard G, Nielsen R, Willnow TE, Devuyst O, Nexo E, Verroust PJ, Christensen El, Kozyraki R: Cubilin is essential for albumin reabsorption in the renal proximal tubule. J Am Soc Nephrol 2010, 21(11):1859-1867.

27. Navar LG: The intrarenal renin-angiotensin system in hypertension. Kidney Int 2004, 65(4):1522-1532.

28. Kobori H, Nangaku M, Navar LG, Nishiyama A: The intrarenal renin-angiotensin system: from physiology to the pathobiology of hypertension and kidney disease. Pharmacol Rev 2007, 59(3):251-287.

29. Galle J: Reduction of proteinuria with angiotensin receptor blockers Nat Clin Pract Cardiovasc Med 2008, 5(Suppl 1):S36-S43.

30. Carter B, Hunsicker L, Lewis S, Orland B, Rodby R: Emerging trends for prevention and treatment of diabetic nephropathy: blockade of the RAAS and BP control. Evid-Based Approach 2004, 10:12-17.

31. Tojo A, Onozato ML, Kurihara H, Sakai T, Goto A, Fujita T: Angiotensin II blockade restores albumin reabsorption in the proximal tubules of diabetic rats. Hypertens Res 2003, 26(5):413-419.

32. Hosojima M, Sato H, Yamamoto K, Kaseda R, Soma T, Kobayashi A, Suzuki A, Kabasawa H, Takeyama A, Ikuyama K, et al: Regulation of megalin expression in cultured proximal tubule cells by angiotensin II type $1 \mathrm{~A}$ receptor- and insulin-mediated signaling cross talk. Endocrinology 2009, 150(2):871-878.

33. Davalli P, Carpene E, Astancolle S, Viviani R, Corti A: Cadmium induction of renal and hepatic ornithine decarboxylase activity in the rat. Effects of sex hormones and involvement of the renin-angiotensin system. Biochem Pharmacol 1992, 44(4):721-726.

34. Varoni MV, Palomba D, Macciotta NP, Antuofermo E, Deiana G, Baralla E, Anania V, Demontis MP: Brain renin-angiotensin system modifies the blood pressure response to intracerebroventricular cadmium in rats. Drug Chem Toxicol 2010, 33(3):302-309.
35. Lall SB, Peshin SS, Gulati K, Khattar S, Das N, Seth SD: Involvement of renin-angiotensin system in hypertensive effect of cadmium in rats. Indian J Exp Biol 1997, 35(4):338-391.

36. Edgell K: USEPA Method Study 37 - SW-846 Method 3050 Acid Digestion of Sediments, Sludges, and Soils. In EPA Contract No 68-03-3254. Edited by EPA. United States: Environmental Protection Agency, Enviromental Monitoring Systems Laboratory; 1989:2-5.

37. Gerard-Monnier D, Erdelmeier I, Regnard K, Moze-Henry N, Yadan JC Chaudiere J: Reactions of 1-methyl-2-phenylindole with malondialdehyde and 4-hydroxyalkenals. Analytical applications to a colorimetric assay of lipid peroxidation. Chem Res Toxicol 1998, 11(10):1176-1183.

38. Molina-Jijon E, Tapia E, Zazueta C, El Hafidi M, Zatarain-Barron ZL, Hernandez-Pando R, Medina-Campos ON, Zarco-Marquez G, Torres I, Pedraza-Chaverri J: Curcumin prevents $\mathrm{Cr}(\mathrm{VI})$-induced renal oxidant damage by a mitochondrial pathway. Free Radic Biol Med 2011, 51(8):1543-1557.

39. Maldonado PD, Molina-Jijon E, Villeda-Hernandez J, Galvan-Arzate S, Santamaria A, Pedraza-Chaverri J: NAD(P)H oxidase contributes to neurotoxicity in an excitotoxic/prooxidant model of Huntington's disease in rats: protective role of apocynin. J Neurosci Res 2010, 88(3):620-629.

40. Bedard K, Krause KH: The NOX family of ROS-generating NADPH oxidases: physiology and pathophysiology. Physiol Rev 2007, 87(1):245-313.

41. Modlinger P, Chabrashvili T, Gill PS, Mendonca M, Harrison DG, Griendling KK, Li M, Raggio J, Wellstein A, Chen Y, et al: RNA silencing in vivo reveals role of p22phox in rat angiotensin slow pressor response. Hypertension 2006, 47(2):238-244.

42. Wolf G, Ritz E: Combination therapy with ACE inhibitors and angiotensin II receptor blockers to halt progression of chronic renal disease: pathophysiology and indications. Kidney Int 2005, 67(3):799-812

43. Lauwerys RR, Bernard A, Roels HA, Buchet JP, Viau C: Characterization of cadmium proteinuria in man and rat. Environ Health Perspect 1984, 54:147-152.

44. Chaumont A, Nickmilder M, Dumont X, Lundh T, Skerfving S, Bernard A: Associations between proteins and heavy metals in urine at low environmental exposures: evidence of reverse causality. Toxicol Lett 2012, 210(3):345-352.

45. Gekle M: Renal tubule albumin transport. Annu Rev Physiol 2005, 67:573-594.

46. Birn H, Fyfe JC, Jacobsen C, Mounier F, Verroust PJ, Orskov H, Willnow TE, Moestrup SK, Christensen El: Cubilin is an albumin binding protein important for renal tubular albumin reabsorption. J Clin Invest 2000, 105(10):1353-1361.

47. Oroszlan M, Bieri M, Ligeti N, Farkas A, Meier B, Marti HP, Mohacsi P. Sirolimus and everolimus reduce albumin endocytosis in proximal tubule cells via an angiotensin II-dependent pathway. Transp/ Immunol 2010, 23(3):125-132.

48. Prozialeck WC, Vaidya VS, Liu J, Waalkes MP, Edwards JR, Lamar PC, Bernard AM, Dumont $X$, Bonventre JV: Kidney injury molecule- 1 is an early biomarker of cadmium nephrotoxicity. Kidney Int 2007, 72(8):985-993.

49. Herak-Kramberger CM, Brown D, Sabolic I: Cadmium inhibits vacuolar H (+)-ATPase and endocytosis in rat kidney cortex. Kidney Int 1998, 53(6):1713-1726.

50. Ahn DW, Chung JM, Kim JY, Kim KR, Park YS: Inhibition of renal $\mathrm{Na}+/ \mathrm{H}+$ exchange in cadmium-intoxicated rats. Toxicol Appl Pharmacol 2005, 204(1):91-98.

51. Wang L, Chen D, Cao J, Liu Z: Protective effect of N-acetylcysteine on experimental chronic cadmium nephrotoxicity in immature female rats. Hum Exp Toxicol 2009, 28(4):221-229.

52. Lee WK, Thevenod F: Novel roles for ceramides, calpains and caspases in kidney proximal tubule cell apoptosis: lessons from in vitro cadmium toxicity studies. Biochem Pharmacol 2008, 76(11):1323-1332.

53. Zhou YJ, Zhang SP, Liu CW, Cai YQ: The protection of selenium on ROS mediated-apoptosis by mitochondria dysfunction in cadmium-induced LLC-PK(1) cells. Toxicol In Vitro 2009, 23(2):288-294.

54. Thevenod F, Friedmann JM: Cadmium-mediated oxidative stress in kidney proximal tubule cells induces degradation of $\mathrm{Na}+/ \mathrm{K}(+)$-ATPase through proteasomal and endo-/lysosomal proteolytic pathways. FASEB J 1999, 13(13): 1751-1761.

55. Thijssen S, Cuypers A, Maringwa J, Smeets K, Horemans N, Lambrichts I, Van Kerkhove E: Low cadmium exposure triggers a biphasic oxidative stress response in mice kidneys. Toxicology 2007, 236(1-2):29-41. 
56. Chen J, Shaikh ZA: Activation of Nrf2 by cadmium and its role in protection against cadmium-induced apoptosis in rat kidney cells. Toxicol Appl Pharmacol 2009, 241(1):81-89.

57. Groppa MD, lanuzzo MP, Rosales EP, Vázquez SC, Benavides MP: Cadmium modulates NADPH oxidase activity and expression in sunflower leaves. Biol Plantarum 2012, 56(1):167-171.

58. Kim SM, Kim YG, Jeong KH, Lee SH, Lee TW, Ihm CG, Moon JY: Angiotensin II-induced mitochondrial Nox4 is a major endogenous source of oxidative stress in kidney tubular cells. PLoS One 2012, 7(7):e39739.

59. Caruso-Neves C, Kwon SH, Guggino WB: Albumin endocytosis in proximal tubule cells is modulated by angiotensin II through an AT2 receptor-mediated protein kinase B activation. Proc Natl Acad Sci USA 2005, 102(48):17513-17518.

60. Fouad AA, Jresat I: Captopril and telmisartan treatments attenuate cadmium-induced testicular toxicity in rats. Fundam Clin Pharmacol 2013, 27(2):152-160

61. Fouad AA, Jresat I: Protective effect of telmisartan against cadmium-induced nephrotoxicity in mice. Life Sci 2011, 89(1-2):29-35.

62. Banes AK, Shaw S, Jenkins J, Redd H, Amiri F, Pollock DM, Marrero MB: Angiotensin II blockade prevents hyperglycemia-induced activation of JAK and STAT proteins in diabetic rat kidney glomeruli. Am J Physiol Renal Physiol 2004, 286(4):F653-F659.

doi:10.1186/1471-2369-14-211

Cite this article as: Santoyo-Sánchez et al:: Impaired endocytosis in proximal tubule from subchronic exposure to cadmium involves angiotensin II type 1 and cubilin receptors. BMC Nephrology 2013 14:211.

\section{Submit your next manuscript to BioMed Central and take full advantage of:}

- Convenient online submission

- Thorough peer review

- No space constraints or color figure charges

- Immediate publication on acceptance

- Inclusion in PubMed, CAS, Scopus and Google Scholar

- Research which is freely available for redistribution 